\title{
ТOM \\ Digging deeper? Muddling through? How environmental activists make sense and use of science - an exploratory study
}

\section{Birte Fähnrich}

Abstract

Keywords

DOI

Introduction
This paper focusses on the sense making and use of science by environmental activists. It is based on the assumption that activists - without being scientists or professional science communicators - take up a central role in the environmental discourse concerning the translation of scientific findings and their public dissemination. It is thus asked how environmental activists evaluate the relevance of science for their work, which structures and processes they apply to make sense of science, and how they use science related information to make their voices heard. This paper presents data from a study on Canadian activists regarding their use of scientific information in the field of forest protection. The data, interpreted in the context of a situational analysis, helps to enhance understanding of environmental activists' information systems but also show the strategic use of scientific information by these alternative science communicators.

Environmental communication; Informal learning; Public perception of science and technology

https://doi.org/10.22323/2.17030208
Environmental activists are considered to be knowledgeable experts in the environmental issues that they are advocating. But, what does being an expert mean, and how do environmental activists develop their expertise?

In the so-called knowledge society [Stehr, 1994], expertise is closely connected to scientific knowledge and information. Being an expert means to possess specific knowledge that is rooted in science as well as being well informed about the latest scientific developments in the respective area of expertise [Stehr and Grundmann, 2010]. Environmental activists are important voices in the field of environmental communication and policy. They aim to influence political, economic, and civic decision-making and action in order to initiate or prevent social change [Schmidt, 2012]. They compete with other societal actors for public attention, interpretational sovereignty, and acceptance [Bennett, 2003]. However, activists only have limited resources to mobilize for their respective issues and, thus, need to rely on effective communication [Schwarz and Fritsch, 2014]. 
In public and policy discourse, environmental issues such as water pollution, forest protection, and climate change are often explained with reference to science derived from various disciplines [Funtowicz and Ravetz, 1993]. Consequently, environmental issues and their complexity are difficult for laymen to understand. Environmental communication variously overlaps with the field of science communication, and activists refer to and use scientific evidence to substantiate their arguments when competing with other societal actors for public and political attention [Cox, 2013]. They thus take up a central role in the environmental discourse concerning the translation of scientific findings and their public dissemination [Bultitude, Rodari and Weitkamp, 2012; Doyle, 2009]. Accordingly, it is assumed that they depend on science and need to evaluate and deal with science-related information in the course of their everyday work. At the same time, these actors are not scientists and, thus, might lack the relevant science literacy to evaluate scientific information or to cope with uncertain and conflicting evidence [Eden, 2010]. Against this backdrop, this paper addresses the question of how environmental activists make use and sense of science. It asks how environmental activists evaluate the relevance of science for their work, which structures and processes they apply to make sense of science, and how they use science related information to make their voices heard, which are directed to political actors or the public at large.

Based on the state of the art and the identification of research gaps referring to activists as "alternative science communicators" [Maeseele, 2009], the paper presents data from a study of Canadian activists regarding their use of scientific information in the field of forest protection as a specific field of environmental communication. The interview results are presented in the framework of situational analysis [Clarke, 2003] and are used to answer the research questions as well as to point to remaining desiderata for prospective research.

State of the art: environmental activists as alternative science communicators
With increasing scientific attention on public communication regarding environmental issues and climate change, research on communication by environmental activists has been on the rise. However, the field of research is highly heterogeneous, and arises from various fields, each consisting of specific issues. Approaches dealing with activist communication can be systematized according to various dimensions [Schmidt, 2012], e.g., with regard to certain environmental issues [the most prominent being climate change, e.g., Tokar, 2015; Nisbet and Kotcher, 2009; with regard to forest protection e.g. Schirmer, 2013], target groups such as political actors [Bryner, 2008], economic actors [Spar and La Mure, 2003] or the public at large, instruments and media such as campaigns, symbolic events, media relations, and social media communication [Doyle, 2009; Greenberg, Knight and Westersund, 2011; Jun, 2011], as well as strategies such as framing [Nisbet and Kotcher, 2009; Reber and Berger, 2005]. However, previous research has devoted little attention to the internal assumptions of environmental non-governmental organizations (ENGOs) [Schwarz and Fritsch, 2014; Johnson and Prakash, 2007], and therefore, activists' rationales and workings, which encompass procedures of information behavior and the strategic use of information, remain understudied. Accordingly, the use of science in environmental communication and activism has been addressed rather sparsely [Eden, 2010; Maeseele, 2009]. However, some researchers from science communication and environmental communication have focused on the intersections of science and environmental communication. Eden [2010, p. 217], for instance, describes specific roles that 
environmental activist organizations play in public and political discourse. She argues that these organizations and the people working with them cannot be considered to be "strictly lay." Not only is the recruitment of scientifically trained personnel regarded as strongly orientating toward science, so too is the "deployment of scientific evidence in their campaigns." However, Eden [2010] refuses to see them as strictly scientific, as they might refer to scientific sources but may hardly generate the science that they deploy. Yearley [2014] points to the reasons for the use of science by environmental activists, which are analyzed in the context of "symbolic legitimacy" [see Cox, 2013]. As NGOs often speak from the margins and lack other power resources, they need to rely on their credibility and trustworthiness; they thus use science-related information to substantiate their arguments and to make their voices heard in the public sphere [Yearley, 2014]. Against this backdrop, environmental activists are regarded as "alternative science communicators" [Maeseele, 2009], who - in addition to scientists themselves, their science organizations [Horst, 2013], and science journalism [Bauer et al., 2013] - contribute to the public communication about and perception of science. Kotcher et al. [2017, p. 264] thus points to certain requirements regarding activists' science communication in seeking to uncover the "kinds of communication efforts" that can "best ensure optimal use of scientific knowledge in policy, without distorting the truth or endangering the long-term credibility and integrity" of science. Here, Yearley [2014, p. 113] assumes that "the persuasiveness of their message depends on the notion that their claims have a basis in factual accuracy." This speaks to studies on the workings and routines of science journalists, who need to deal with scientific information and related problems such as conflicting evidence or insufficient science literacy in their everyday work [Lehmkuhl and Peters, 2016; Wilson, 2000]. Lehmkuhl and Peters [2016], for instance, analyze how journalists deal with scientific uncertainty against the backdrop of their professional norms "to provide the most accurate representation possible because otherwise journalism risks losing credibility" [Lehmkuhl and Peters, 2016, p. 2]. Based on a case study in the field of neuroscience, they found that journalists deal with uncertainty by omission, by contrasting conflicting messages, or by explicitly addressing the problem. However, it is assumed that these normative demands and value-based assumptions do not cope with the workings of environmental activists for at least two reasons, which have hardly been addressed in previous research. First - and contrary to other professional science communicators such as science journalists - environmental activists necessarily speak from "value positions" and always pursue certain interests. Accordingly, they may even attempt to open up environmental debates by deliberately challenging notions of expertise, scientific certainty, and issue closure [Eden, 2010]. Against this backdrop, it is debatable whether activists are willing to follow the normative demands and value systems of science and science communication. Instead, it is assumed that the use of scientific information and evidence by environmental activists cannot be neutral and objective. Second, it is argued that activists - even if they were willing - might not be able to meet these demands. As alternative science communicators, they "must rely on or judge claims which they cannot epistemically fully own, that is to say other people's knowledge which they [...] can't judge as a peer" [Turner, 2007, S. 41]. However, it is not known how these non-scientific actors translate scientific information into their individual epistemology [Jasanoff, 2012] and professional contexts, which processes and practices they apply, and which strategies underlie these translation processes. 
Sense making as a In addition to work in areas such as experimental research [Yeo et al., 2017], conceptual framework questions about the reception of scientific information, the processes of its individual appropriation, and its strategic use have also been asked in the course of sense-making research, albeit sparsely and with a focus on lay people. For instance, Ryghaug, Sørensen and Næss [2011] explored how Norwegian lay people understand global warming. While climate change has become one of the most prominent subjects of science communication research, and communication about climate change is often considered highly scientific, their research suggests that (mass-mediated) scientific information is only one of the factors influencing the knowledge building on the subject. Faber et al. [2010] investigated sense making in the area of sustainability; however, they were mainly interested in the assessment of knowledge and less in the underlying processes. In an application-based approach, Dervin and Foreman-Wernet [2013] applied sense making to campaigning techniques, arguing that it was important for effective (environmental) communication and campaign design to know the audience and their processes of understanding and appropriation. With a view to this work, the sense-making approach provides a suitable theoretical framework for the analysis of environmental activists' use of scientific information. This is explained next in more detail to provide a basis for the empirical study.

Sense making is not a coherent theory or model but a conceptual framework. The approach has its roots in organizational psychology and management research. It follows the idea that "there is more to life than decision making ... and much of this 'more than' precedes decision making" [Weick, 2001, p. x]. Dervin [2003a] and Dervin [2003b] assumed that information (as a requirement for knowledge) cannot be normative or absolute. Instead, information is considered a "user construct." According to Dervin [2003b], "efforts at predicting information use [are regarded] as being a direct reflection of the nature of the assumptions being made about information" (p. 113). Thus, sense making refers to "information needs, seeking and use in different contexts" (p. 111). By looking at the "how" of communication, such as how social actors define situations, how they are influenced by past experiences, and how they relate to future expectations, this approach provides a framework for understanding and comparing communicative behavior [Foreman-Wernet, 2003, p. 9]. Therefore, the sense-making approach requires "respondent-centered and open-ended measurement techniques".

Method and research design
To make this research as open and exploratory as possible, interviews with Canadian environmental activists were conducted on how environmental activists evaluate scientific information for their work and use it in professional contexts. The data collection and analysis followed the situational analysis approach [Clarke, Friese and Washburn, 2018]. The sample is described in the next section, followed by the method and research design.

\section{Sample}

The data were collected during the author's research visit in Victoria, British Columbia (BC), Canada. Canada, particularly the province of BC, has a strong tradition in the field of environmental activism. In the 1990s, BC had the highest density of NGOs in Canada [Blake, Guppy and Urmetzer, 1997]. Large 
international environmental organizations such as Greenpeace have their origins in the province. In Canada as well as internationally, the environmental activism movement has been a serious social force since the 1960s. Especially since the 1970s and 1980s, its development has also been characterized by sensational and sometimes militant actions. According to Blake, Guppy and Urmetzer [1997, p. 456],

Their [environmental organizations'] tactics have included an invasion of the provincial legislature and massive protests over clear-cut logging. Attempts to begin logging in Clayoquot Sound in 1993 led to one of the largest acts of civil disobedience in Canadian history and the arrest of over 800 protesters, including a prominent member of parliament.

In BC, due to the strong influence of forestry [Schirmer, 2013], the major focus areas of environmental activist groups are the protection of forests - particularly the old naturally grown trees in the primeval forests (old-growth forest) - the preservation of biodiversity, and the support of indigenous peoples (First Nations) who are still partial residents in the forested areas. A recent major achievement of the environmental activists' movement was the provincial government's decision to protect the Great Bear Rainforest, the world's largest coastal rainforest in a temperate climatic zone. The agreement had been preceded by more than 20 years of intense protests and negotiations, with strong participation by environmental groups [Hunter, 2016]. Equally involved were internationally active environmental organizations (e.g., Greenpeace and Sierra Club), nationally active organizations (e.g., Wilderness Committee and the Canadian Park and Wilderness Society), and BC-focused environmental NGOs (ENGOs) such as Ancient Forest Alliance.

Accordingly, interlocutors from all three types of organizations working in the field of forest protection were selected for the interviews. The sample was composed of seven activists on various hierarchical levels from the campaigner, who is also responsible for the implementation of activities and communication measures, to the executive director, who is in charge of the general strategic orientation of the ENGO. Participants had several years of professional experience in the ENGO sector but differed in their professional background and education (e.g., academic degree, study subjects, previous professional experience, and international experience). While some of the interviewees also had an academic education (bachelor's or master's level) in science, none of the participants had been working in academia. Table 1 gives an overview of the interview participants and their status in their respective organizations at the time of the interview. It is acknowledged that the sample size of seven might appear small. More activists had been invited for interviews, but the number of people working on forest issues in the BC context is limited and there were some rejections (basically due to a lack of time). However, the number of interviews meets the requirements for an exploratory study, and the strictly qualitative approach is meant to give a glimpse into this underresearched field but not to come to generalized conclusions.

\section{Data collection and analysis}

The interviews took an average of one hour each and were conducted personally or via Skype. They were semistructured but still provided a high degree of openness to allow a situation in which the interviewee could circle around the given 
Table 1. Overview of the interviewees.

\begin{tabular}{|l|l|l|}
\hline Interviewee & Position & Organization \\
\hline Int_1 & Executive Director & Ancient Forest Alliance \\
Int_2 & Senior Campaigner & Greenpeace \\
Int_3 & Executive Director & Canadian Park and Wilderness Society \\
Int_4 & Program Director & Canadian Park and Wilderness Society \\
Int_5 & Campaigner & Wilderness Committee \\
Int_6 & Campaigner & Sierra Club \\
Int_7 & Senior Campaigner & Sierra Club \\
\hline
\end{tabular}

phenomenon or situation [Foreman-Wernet, 2003, p. 4]. The interview guide used three main themes to structure the discussion:

1. the relevance of scientific information to the activist's fulfillment of his or her duties

2. the practices, sources, and structures for the research and selection of scientific information

3. the use and application of scientific information in daily work

The interviews were conducted between June and August 2016. They were transcribed and analyzed against the backdrop of the research questions.

Data collection and analysis followed the situational analysis approach [Clarke, 2003; Clarke, Friese and Washburn, 2018]. Situational analysis is a postmodern version of grounded theory that allows the analysis of individual actions within complex social constellations and makes visible "all the key elements in the situation and their interrelations; the social worlds and arenas in which the phenomena of interest are embedded; and the discursive positions taken and not taken by actors." [Clarke, 2003, p. 572] In the context of situational analysis, "the situation per se" is the central unit of examination. Clarke, Friese and Washburn [2018, p. 17] applied the following broad definition of a situation:

a situation is not merely a moment in time, a narrow spatial or temporal unit or a brief encounter or event ... Rather it usually involves a somewhat enduring arrangement of relations among many different kinds and categories of elements ... It usually includes a number of events over at least a short period of time, and can endure considerably longer.

Situational analysis reveals the complex interdependencies and structures within the situation that exist between individuals, collectives, institutions, nonhuman actors, discourses, technologies, symbols, images, histories, and the like. In this sense, maps contribute to a "social inversion" by also capturing the invisible and incomplete elements or links in a situation. This global approach or "big picture analysis" [Clarke, Friese and Washburn, 2018, p. 150], which can also integrate different forms of data, distinguishes situational analysis from other methods of qualitative social research. However, in accordance with other interpretive 
methods - and in clear contrast to quantitative approaches - situational analysis does not intend to claim the full objectivity and validity of the results it produces. As Clarke, Friese and Washburn [2018, p. 19] explained, "an analysis of any kind is no more than one or few readings of a situation - understandings or interpretations.

... Instead, analyses are understood to be partial, historical, situated."

Situational analysis is based on the development of and work with different "maps," which in each case allow different access to the data material. Clarke, Friese and Washburn [2018, p. xxiv] distinguished three types of maps:

1. Situational maps that lay out the major human, nonhuman, discursive, affective, geopolitical and other elements in the research situation of inquiry and provoke analysis of relations among them

2. Social worlds/arenas maps that lay out the major collective actors (social worlds, organizations, institutions, etc.) and the arena(s) of commitment and discourse with which they are engaged in ongoing negotiations in the situation of inquiry

3. Positional maps that lay out the major positions taken, and not taken, in discussions, debates, and extant discourse materials in the situation of inquiry vis-à-vis particular axes of difference, concern, and controversy about important issues

In combination with memos which are used to log the interpretation process, the maps are applied as heuristic tools. Used in the intermediate stages of analysis, they can also serve to further develop the adaptation of survey instruments. Correspondingly, situational maps were also used in the context of this survey to adjust the interview guide. In the context of data analysis and interpretation, the maps provide an analysis of data and a visualization of this analysis - for instance, with regard to constellations of researched actors in the specific arenas in which they operate or the specific positions that they hold within a discourse.

The presentation of results draws on the three central topics of environmental activists' sense making in dealing with scientific information. The focus is on (1) the relevance of scientific information; (2) the practices, sources, and structures for research and selection; and (3) the use of scientific information in daily work. Findings and their interpretations are based on the development of situational maps, social worlds maps, and positional maps as part of the data analysis; these maps are also partly used for visualization. To give a better sense of the activists' positions, selected quotes from the interviews are added to the discussion of findings. In the context of situational analysis, however, the focus is less on the assignment of positions to individual actors or actor types; instead, the objective is to give a comprehensive outline of the activists' situation and the discourses in which they are involved.

Situational maps were first used to approach the data and to position elements and their links in the research situation and context [Clarke, Friese and Washburn, 2018]. They showed that the actors have multiple contacts with scientific information 
in their everyday work. This applies to both the topics they deal with as well as the specific structures of interpersonal relationships and patterns of action. The individual elements are closely interrelated; for example, the question of the relevance of scientific information to activists cannot be separated from the daily routines, interactions, relationships, and discourses in which they are involved.

From an issue-related perspective, the field of forest protection - in accordance with other fields of environmental activism - is a field in which expertise and specialist knowledge is highly grounded in scientific information. Primarily relevant are ecological knowledge resources, in addition to some sociological, ethnographic (e.g., with regard to the First Nations), and economic (e.g., with regard to forestry) resources.

With regard to the relevance of scientific knowledge in the context of specific interactions and relationships, significant differences emerge. Depending on the level of interaction (e.g., with other activists, political actors, or civil society), scientific informedness seems to be more or less relevant to activists; this aspect will be discussed in more detail below. Besides these interactions with human actors, there are also patterns of interaction with nonhuman actors such as Google, mass media, and (scientific) journals.

The analysis primarily referred to processes and procedures that relate to the research, selection, and analysis of science-related information. Overall, findings show that respondents hardly reflect on individual and organizational information processes. It is only the situation of inquiry that leads them to reflect on the relevance of scientific information in the context of their work and to reflect on their individual sense making. These topics and behavior patterns are highly automated processes and do not seem to be the object of professional consideration. As one of the interviewees stated, "Honestly, these questions really stretched my mind. I have never thought about these things before" (Int_1).

\section{Relevance of scientific information}

If one understands the social space in which the activists act as an arena and "discursive site" [Clarke, Friese and Washburn, 2018, p. 148], the use of scientific information can also be seen as a discourse in the sense of a comprehensive social context [see also Strübing, 2014, p. 103]. This takes place in various social worlds [Clarke, Friese and Washburn, 2018] in which the activists are involved. Centrally, there are different fields of action ["action as process"; Clarke, Friese and Washburn, 2018, p. 150] as well as different fields of interaction ["units of action"; Clarke, Friese and Washburn, 2018, p. 150] in which scientific information has different meanings for the activists (see also Figure 1). Within the framework of the relationships in the activist's own organization and in the social networks of the (environmental) activist scene, scientific knowledge and information function as criteria of social recognition and are also used as a "currency," which (co-)determines the activist's social status within the community. Individuals with specific scientific knowledge are considered experts and act as advisors within the ENGO or in the context of cooperation with other environmental activist groups.

For instance, an interviewee (Int_6) described as follows: 
[He] is helping me a lot because he has been around for a long time, he is very competent at what he does, and he spent a lot of time self-educating ... he just sends me stuff, if he reads something or picks up an article at Nature magazine ... so then I get brought up to speed on that subissue.

Similarly, reports and documentation from other ENGOs at the organizational level are considered an important source of information. The relevance of being scientifically informed is rated differently depending on the task in focus. Thus, within the social world of ENGO research and further education, being scientifically informed is regarded as crucial within the overall task portfolio of the activists. In this situation, science-based information is considered more valuable than information from other sources because it provides a central orientation in the information process. However, this applies only to information in certain thematic fields of work, not to the development of specific skills (e.g., campaigning and monitoring). In the context of exchange and networking with other activists, scientific information also plays an important role and is actively addressed and discussed in the context of interactions. But there are hardly any formal procedures within ENGOs (in the sense of strategic knowledge management). There are differences especially with regard to the size and resources of the organizations. In principle, a certain (scientifically based) expertise in the respective thematic field of work is considered a prerequisite to join ENGOs (e.g., in the context of staffing).

The use of scientific information is also seen as a criterion to differentiate professional ENGOs at the organizational level and activists at the individual level from less professional ones. According to Int_1, "The more professional and experienced the organization is, the more they tend to look more closely and accurately at the evidence." Expertise and the orientation to scientific facts ("scientific truth") are juxtaposed with an ideological and emotion-driven orientation ("ideological truth"), whereby the former is normatively considered desirable.

While science-based information is regarded as highly relevant when interacting with other activists, it is less important when dealing with political actors (e.g., in the context of negotiation processes and hearings). The interviewees agreed that environmental organizations are regarded as expert organizations by political actors. However, expertise and background knowledge is primarily seen as a prerequisite to access the political level. In the concrete interaction and debate on specific environmental issues, scientific facts play a subordinate role. As Int_4 explained,

When you are talking to political actors, you are staying at a very high level ... it is more about making sure that I am very comfortable with what I am saying. And if anybody asks me a question, I can feel confident that I can answer them based on pretty good evidence and fact-based information.

Moreover, the interaction with political actors is shaped by another interrelation, as political organizations are a central source of information and research for activists. They usually commission scientific reports and make them publicly available. These reports are used by activists as a trustworthy source of information. As Int_1 stated, "a lot of government sources are essentially academic." 
In the interaction with nonprofessionals (e.g., those affected by problems in certain environmental protection measures) and the general public, scientific expertise does not seem to play a major role. According to Int_3,

To the general public, the science may or may not be as important as how they emotionally feel about an issue... It can be mildly persuasive, but the general public is much more persuaded by sort of the emotional idea.

Science-related informedness is - as compared to the interaction with political actors - considered important to ensure credibility and to guarantee an expert status, but it is still viewed as a "quiet" resource that is only used in conflict situations (e.g., when positions and opinions are actively challenged by others). The situation is similar in interactions with representatives of the (forestry) industry and other interest-based organizations. Int_1 provided the following example: "When I talk to the Chamber of Commerce, I am not talking about biodiversity ... I am only talking about a win-win situation." However, activists are clearly positioning themselves in these situations, and they admit knowledge gaps by pointing out that they are activists and not scientists.

The interaction with media - both journalistic media and social media such as Facebook - as nonhuman actors [Clarke, Friese and Washburn, 2018] is particularly important in terms of research and general information. They are the central source of information. For instance, Int_4 shared, "I actually love Google, because I just try to figure out everything that was written on the topic and start reading those documents." But scientific information is often not actively researched. Rather, activists come across relevant information in the daily press or in social media and only then begin to engage more closely with the respective science. Finally, scientists and scientific publications constitute another important field of interaction, especially in the context of the sense making and understanding of specific environmental problems and issues in the activists' work. Activists here take the position of (informed) lay people who ask for advice and help, whereas scientists are perceived as experts and authorities on the one hand and as accomplices of environmental activism and its beliefs on the other.

Figure 1 maps the different fields of action (basically working areas, tasks, routines) and the fields of interaction (relations to certain stakeholder/actor groups) of the activists and the relevance that science and science related informedness play in the respective fields. It is important to note that - in accordance with the focus of this paper - the interrelations outlined in the map display only the activists' perspective. Fields of interaction and the relevance of science in these connections derive from the statements made by the activists in the interviews. The same applies to the assumed relevance of science in the different fields. Based on the activists" assessment a high relevance of science in a certain field of action or interaction is indicated with $(+++)$, a low relevance is indicated with $(+)$.

Practices, sources and structures for research and selection

Questions about activists' sense making also focus on how the actors research, select, and transfer scientific information within their own contexts of action. The 


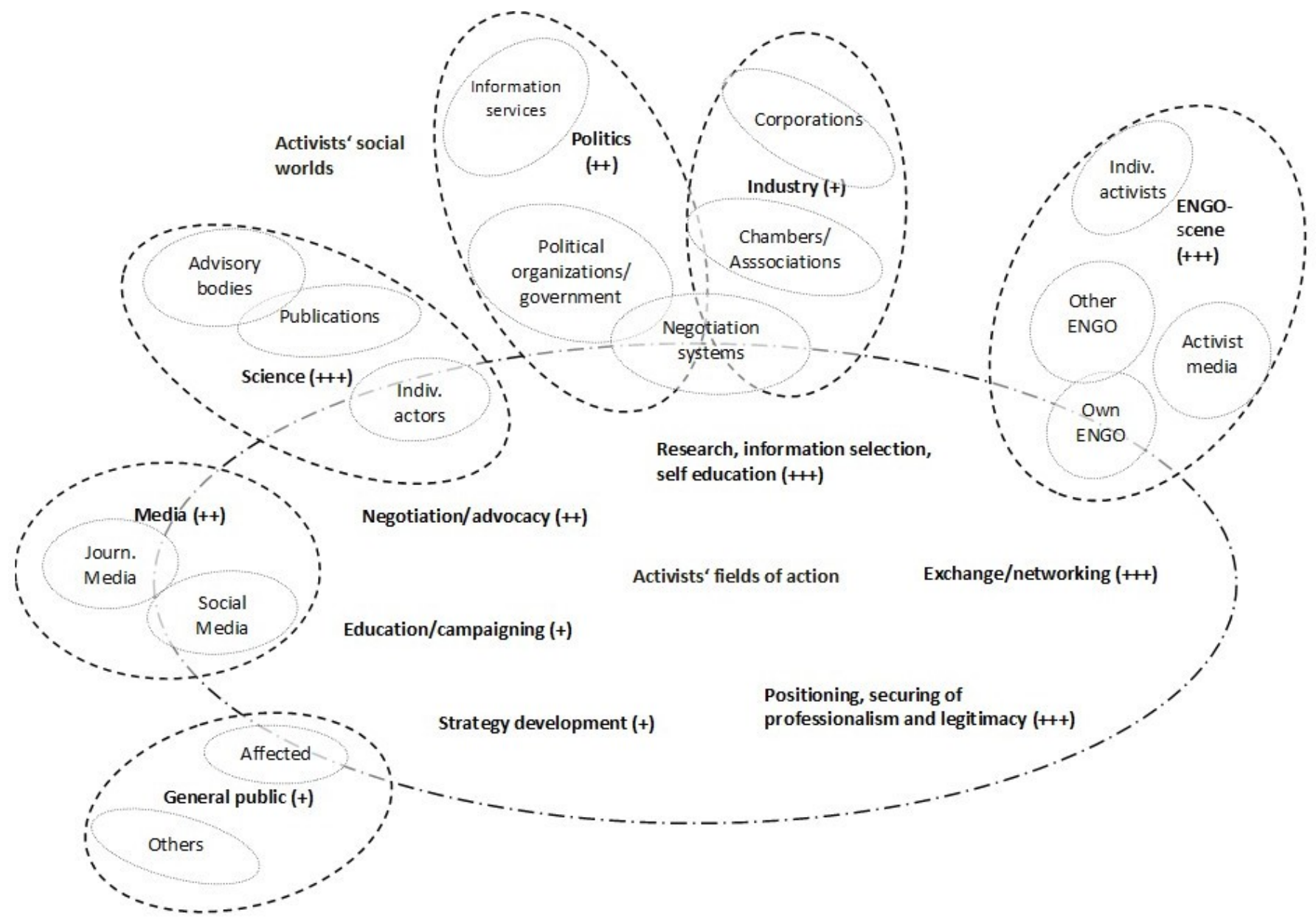

Figure 1. Social world map: fields of action and interaction and the relevance of being scientifically informed. Assumed relevance ranges from low (+) to high (+++).

focus of this analysis, however, is not to describe or measure concrete processes and practices but rather to capture the positions that environmental activists take on these questions - and which should therefore be assumed as leading their actions in their everyday work.

In the context of situational analysis, the positional maps depict the various facets of a discourse. According to Clarke, Friese and Washburn [2018, p. 166], “The goal is to represent all the major positions articulated in the materials on their own terms." An analysis of environmental activists' sense making of scientific information can also be conducted with regard to normative assessments: the focus will then be on the activists' respective strategies and their justifications and evaluations for the research, selection, and use of scientific information in the context of their actions.

The positional map (Figure 2) shows diverse and quite contradictory positions. On the one hand, environmental activists per se emphasize the credibility of scientific versus other sources: "If I know there is a professor who I know posts reputable things ... then I follow them and read the things that they are posting" (Int_5). Accordingly, academic standards are considered important. To search for information, the activists consult governmental or activist media as well as 
scientific databases and publications, adapt scientific working methods (e.g., focusing on references cited within a paper to research further sources), or visit scientific conferences to keep up to date: "So I read those [scientific] documents and I looked at the citations of those documents. And I often read the papers that they cited" (Int_4).

In the selection of information, the activists continue to adopt scientific standards, as peer-reviewed articles are considered the most credible. Specific reputation criteria of science are also adapted. This applies, for example, to the evaluation of universities where scientists work, and which are included in the assessment of the quality of scientific information. Moreover, the respective positions of the scientists and the context in which specific research is developed are taken into account.

\section{Use of scientific information}

In contrast to the research and selection processes, the orientation toward scientific standards varies when it comes to the use of scientific information. Here, the activists show quite pragmatic approaches. In view of the challenges that can arise in the understanding of scientific publications, while it is desirable, it is not necessary and sometimes not possible to understand these publications entirely (e.g., with regard to the methods used). What seems to be important is that the conclusions are understandable. Activists also see themselves as mediators who bring scientific information to the general public and translate it into an understandable language. As Int_3 put it, "A lot of what we do is trying to understand what these ecological experts are saying about an area and putting it into language that everybody is going to relate to and understand." In the same way, activists show a rather utilitarian use of scientific information in their daily work. To refer to scientific findings is considered an important prerequisite for the credibility and trustworthiness of one's own reasoning. The selection of scientific information must then also correspond to the activists' positions on the environmental problem: "It is to show where the evidence actually fits in the issues that you are talking about" (Int_1). Consequently, this means that the actors distinguish between "good" and "bad" science. This also applies if new evidence contradicts previous assumptions and existing positions. Describing one such situation, Int_6 shared, "A lot of environmentalists called bullshit on that and said, well, this is problematic science." This is also reflected in their actions when selecting and using science. However, this handling of contradictory scientific evidence is reflected upon and viewed critically: "I don't think it is a good practice for us to use science when it works in our favor and disregard science when it doesn't work in our favor" (Int_3).

Linked with this perspective is the need to secure the activists' public credibility and legitimacy, as ENGOs and the scene in general are regarded to have a certain social responsibility. Against this backdrop, the relevance of science is to some extent qualified in relation to activists' work. According to Int_1, "A lot of times, people can trust the research that actually doesn't mean anything in relation to what we're saying." In this context, the activist's own ideological position gains more weight. Int_4 shared, "even if the science says the population is very healthy, it is ok if we kill some of the habitat, it's still morally wrong. So we usually blend that pretty heavy." At the same time, research should not be an "end in itself." 
Orientation to activists' goals

Orientation to scientific standards

Science that does not make sufficient reference to real-world problems is rated critically. Int_4 reflected on this as follows: at this point, you think of how much research and literature has gone into salmon research and think about how much of that is eventually translated into anything that benefits salmon. ... if we're not willing to put what we know into practice, then what does it matter what we know?

Scientific findings can also be problematic if they contradict moral assessments.

ENGO are an important facilitator/ translator of scientific information.

\author{
Complete understanding \\ of scientific information is \\ not necessary.
}

Scientific references strenghten credibility.
Social responsibility should urge to scientific correctness.
The evidence should fit with your own arguments.
Scientific reputation criteria are an important indicator for information selection.
Just because something is scientific (proven), it does not need to be relevant.

\author{
Scientific information is a \\ striking argument against \\ opposing positions.
}

The results of the study on Canadian environmental activists show that scientific informedness is vital for these actors in the context of their work. However, there are central differences regarding the activists' fields of action and dimensions of interaction. To know the current state of research in their respective fields of work seems to be most important in the activist scene. There, such an expertise also serves as a currency for social recognition and status at the level of individual actors, for the evaluation of the professionalism of ENGOs at the organizational level, and for the attribution of credibility to environmental activism as a whole at the social level. These findings confirm the thesis that activists refer to science as a "tool" for securing "symbolic legitimacy" [Yearley, 2014].

Nevertheless, the influence of science-related information appears to be limited in interaction with actors from politics, business, and the public. Here, science is used as a "quiet" resource to prove that one is a serious opponent. Although environmental activists view scientific references as important to their work and even adopt certain norms and standards of science (e.g., in relation to peer-review processes, journal rankings, and reputation criteria), their sense-making procedures in dealing with science do not necessarily correspond to these assessments.

Activists use scientific information largely unconsciously and automatically. There 
are hardly any standardized procedures on an organizational or individual level, and activists rely heavily on personal networks to keep themselves up to date. Although environmental activists seem to adopt more pragmatic strategies in the reception of scientific publications, the use of this information and its transfer into their respective action contexts is clearly strategic. Scientific findings are used quite selectively based on their argumentative fit [Eden, 2010]. Accordingly, these actors are not only "alternative" [Maeseele, 2009] but also "strategic" science communicators. While this result is not entirely surprising, it is still relevant to consider, since environmental activists - in their role as science communicators - might have an important impact on the public visibility and perception of science.

Overall, the results contribute to the discovery of processes and structures underlying the information systems of environmental activists and their communicative behavior. They also contribute to a more comprehensive understanding of the mechanisms of science communication and environmental communication as well as their interfaces [Davis et al., 2018]. Yet this study, due to its exploratory nature, can only give a limited insight into environmental activists' sense making.

This goes along with limitations of the empirical study. Overall, the situational analysis approach proved to be valuable to answer questions in focus. Especially, the mapping - which differentiates situational analysis from other qualitative methods such as content analysis, rhetorical analysis or discourse analysis - was a helpful tool to uncover the internal workings of activists and their sense making and use of science in their everyday work. Moreover, it was also useful to display the results in a structured and comprehensive manner. However, a central limitation of this study lies in the single data source and the focus on only one group of actors. Although this is acceptable in the context of situational analysis, future research should integrate multiple data sources to substantiate the findings and to realize the full potential of the approach [Clarke, Friese and Washburn, 2018].

Against this backdrop, prospective studies could further examine the relevance of scientific information in activism and could encompass the analysis of documents and online sources which activists use in the context of their strategic communication. Moreover, observational techniques would enable to research internal procedures and routines of ENGOs and thus to verify the results of this study. Beyond the activists' perspective a broader approach could also analyze the perception of activists' expertise from the viewpoints of other actors (e.g., politicians and lay people). This could be a useful way to evaluate activists' impact on public science communication.

Moreover, research in the field could also enhance the understanding of science communication and the ways in which science becomes publicly visible. To date, science communication research has merely focused on professional science communicators such as science journalists and PR professionals from science organizations but has widely overlooked the impact that alternative science communicators might have on the public perception of science. With the changing science communication landscape in the context of mediatization we argue that these communicators - namely NGOs, corporations, associations, foundations, consultancies, think tanks etc. - will rise in importance in the communication 
on science related issues in the future. From a societal and normative point of view, the diversification of science communicators can bring about both advantages and disadvantages for the interrelation of science and society. Recent political initiatives have aimed at a democratization of science and have regarded science communication as an important means to bring science and society closer together. In this perspective, the emergence of new science communicators could be regarded as true public engagement with science and as an indicator for the effectiveness of several decades of science communication efforts. However, from a more critical perspective one needs to consider previous cases of science denial, e.g. in the context of climate change, or the latest fake news debate. Against this backdrop, the role of alternative science communicators and their strategic use of science might be fraught with risks and could even threaten the overall credibility of science.

In this context, future research should focus on the role that science might play in activism and related fields. And it should critically evaluate the role that environmental activists and other alternative science communicators play in science communication and the effects that the diversification of the science communicators' landscape has for the entire science communication enterprise.

\section{References}

Bauer, M. W., Howard, S., Romo Ramos, Y. J., Massarani, L. and Amorim, L. (2013). Global science journalism report: working conditions $\mathcal{E}$ practices, professional ethos and future expectations. Our Learning Series. London, U.K.: Science and Development Network.

Bennett, W. (2003). 'Communicating global activism'. Information, Communication $\mathcal{E}$ Society 6 (2), pp. 143-168. https://doi .org/10.1080/1369118032000093860a.

Blake, D. E., Guppy, N. and Urmetzer, P. (1997). 'Canadian public opinion and environmental action: evidence from British Columbia'. Canadian Journal of Political Science 30 (03), p. 451. https: //doi .org/10.1017/s0008423900015973.

Bryner, G. (2008). 'Failure and opportunity: environmental groups in U.S. climate change policy'. Environmental Politics 17 (2), pp. 319-336. https://doi.org/10.1080/09644010801936255.

Bultitude, K., Rodari, P. and Weitkamp, E. (2012). 'Bridging the gap between science and policy: the importance of mutual respect, trust and the role of mediators'. JCOM 11 (3), C01.

URL: https://jcom.sissa.it/archive/11/03/Jcom1103(2012)C01.

Clarke, A. E. (2003). 'Situational analyses: grounded theory mapping after the postmodern turn'. Symbolic Interaction 26 (4), pp. 553-576. https://doi.org/10.1525/si.2003.26.4.553.

Clarke, A. E., Friese, C. E. and Washburn, R. S. (2018). Situational analysis. grounded theory after the postmodern turn. 2nd ed. Thousand Oaks, CA, U.S.A.: Sage.

Cox, J. R. (2013). Environmental Communication and the public sphere. 3rd ed. Thousand Oaks, CA, U.S.A.: SAGE Publications.

Davis, L., Fähnrich, B., Nepote, A. C., Riedlinger, M. and Trench, B. (2018). 'Environmental communication and science communication - conversations, connections and collaborations'. Environmental Communication 12 (4), pp. 431-437. https://doi.org/10.1080/17524032.2018.1436082. 
Dervin, B. (2003a). 'Given a context by any other name: methodological tools for taming the unruly beast'. In: Sense-making methodology reader: selected writings of Brenda Dervin. Ed. by B. Dervin, L. Foreman-Wernet and E. Lauterbach. Cresskill, NJ, U.S.A.: Hampton Press, pp. 111-131.

- (2003b). 'Sense making's journey from metatheory to methodology to method: an example using information seeking and use as a research focus'. In: Sense-making methodology reader: selected writings of Brenda Dervin. Ed. by B. Dervin, L. Foreman-Wernet and E. Lauterbach. Cresskill, NJ, U.S.A.: Hampton Press, pp. 133-163.

Dervin, B. and Foreman-Wernet, L. (2013). 'Sense-making methodology as an approach to understanding and designing for campaign audiences: a turn to communicating communicatively'. In: Public communication campaigns. Ed. by R. E. Rice and C. K. Atkin. Thousand Oaks, CA, U.S.A.: Sage, pp. 146-162. https://doi.org/10.4135/9781544308449.n10.

Doyle, J. (2009). Climate action and environmental activism: the role of environmental NGOs and grassroots movements in the global politics of climate change. Ed. by T. Boyce and J. Lewis. Bruxelles, Belgium: Peter Lang, pp. 103-116.

Eden, S. (2010). 'NGOs, the science-lay dichotomy and hybrid spaces of environmental knowledge'. In: Geographies of Science. Ed. by P. Meusburger, D. Livingstone and H. Jöns. Dordrecht, Netherlands: Springer, pp. 217-230. https://doi.org/10.1007/978-90-481-8611-2_12.

Faber, N. R., Peters, K., Maruster, L., van Haren, R. and Jorna, R. (2010). 'Sense making of (social) sustainability. A behavioral and knowledge approach'. International Studies of Management $\mathcal{E}$ Organization 40 (3), pp. 8-22. https://doi.org/10.2753/imo0020-8825400301.

Foreman-Wernet, L. (2003). 'Rethinking communcation. Introducing the sense-making methodology'. In: Sense-making methodology reader: selected writings of Brenda Dervin. Ed. by B. Dervin, L. Foreman-Wernet and E. Lauterbach. Cresskill, NJ, U.S.A.: Hampton Press, pp. 3-16.

Funtowicz, S. O. and Ravetz, J. R. (1993). 'Science for the post-normal age'. Futures 25 (7), pp. 739-755. https://doi .org/10.1016/0016-3287 (93) 90022-L.

Greenberg, J., Knight, G. and Westersund, E. (2011). 'Spinning climate change: corporate and NGO public relations strategies in Canada and the United States'. International Communication Gazette 73 (1-2), pp. 65-82. https://doi.org/10.1177/1748048510386742.

Horst, M. (2013). 'A Field of Expertise, the Organization, or Science Itself? Scientists' Perception of Representing Research in Public Communication'. Science Communication 35 (6), pp. 758-779. https://doi.org/10.1177/1075547013487513.

Hunter, J. (5th June 2016). 'Final agreement reached to protect B.C.'s Great Bear Rainforest'. The Globe and Mail. URL: https: //www . theglobeandmail . com/news /british-columbia/final-agreement-reached-to-protect-bcs-great-bear -rainforest/article28475362/.

Jasanoff, S. (2012). 'Reason in practice'. In: Science and public reason. Ed. by S. Jasanoff. Abingdon, U.K. and New York, U.S.A.: Routledge, pp. 1-23. https://doi.org/10.4324/9780203113820. 
Johnson, E. and Prakash, A. (2007). ‘NGO research program: a collective action perspective'. Policy Sciences 40 (3), pp. 221-240. https://doi.org/10.1007/s11077-007-9043-x.

Jun, J. (2011). ‘How climate change organizations utilize websites for public relations'. Public Relations Review 37 (3), pp. 245-249. https://doi.org/10.1016/j.pubrev.2011.04.001.

Kotcher, J. E., Myers, T. A., Vraga, E. K., Stenhouse, N. and Maibach, E. W. (2017). 'Does engagement in advocacy hurt the credibility of scientists? Results from a randomized national survey experiment'. Environmental Communication 11 (3), pp.415-429. https://doi.org/10.1080/17524032.2016.1275736.

Lehmkuhl, M. and Peters, H. P. (2016). 'Constructing (un-)certainty: an exploration of journalistic decision-making in the reporting of neuroscience'. Public Understanding of Science 25 (8), pp. 909-926. https://doi.org/10.1177/0963662516646047.

Maeseele, P. A. (2009). 'NGOs and GMOs. A case study in alternative science communication'. Conference Papers. In: 2009 Annual Meeting. (Chicago, IL, U.S.A.). International Communication Association.

Nisbet, M. C. and Kotcher, J. E. (2009). 'A Two-Step Flow of Influence? Opinion-Leader Campaigns on Climate Change'. Science Communication 30 (3), pp. 328-354. https://doi .org/10.1177/1075547008328797.

Reber, B. H. and Berger, B. K. (2005). 'Framing analysis of activist rhetoric: how the Sierra Club succeeds or fails at creating salient messages'. Public Relations Review 31 (2), pp. 185-195. https://doi .org/10.1016/j . pubrev . 2005.02 . 020.

Ryghaug, M., Sørensen, K. H. and Næss, R. (2011). 'Making sense of global warming: Norwegians appropriating knowledge of anthropogenic climate change'. Public Understanding of Science 20 (6), pp. 778-795. https://doi.org/10.1177/0963662510362657.

Schirmer, J. (2013). Environmental activism and the global forest sector. Ed. by E. Hansen, R. Panwar and R. Vlosky. Boca Raton, FL, U.S.A.: CRC Press, pp. 203-235. https://doi.org/10.1201/b16186.

Schmidt, A. (2012). ‘Bewegungen, Gegenbewegungen, NGOs: Klimakommunikation zivilgesellschaftlicher Akteure'. [Movements, counter movements, NGOs: climate communication of civil society actors]. In: Das Medien-Klima. [The media climate]. Ed. by I. Neverla and M. S. Schäfer. Wiesbaden, Germany: Springer, pp. 69-94. https://doi.org/10.1007/978-3-531-94217-9_4.

Schwarz, A. and Fritsch, A. (2014). 'Strategic communication practice of international nongovernmental organizations'. In: The Routledge handbook of strategic communication. Ed. by D. Holtzhausen and A. Zerfass. New York, NY, U.S.A.: Routledge, pp. 459-480.

Spar, D. L. and La Mure, L. T. (2003). 'The power of activism: assessing the impact of NGOs on global business'. California Management Review 45 (3), pp. 78-101. https://doi.org/10.2307/41166177.

Stehr, N. (1994). Knowledge societies. London, U.K.: Sage.

Stehr, N. and Grundmann, R. (2010). Expertenwissen: Die Kultur und die Macht von Experten, Beratern und Ratgebern. [Expert knowledge. The culture and power of experts, advisors and consultants]. Weiland, Deutschland: Velbrück. 
Strübing, J. (2014). Grounded theory. Zur sozialtheoretischen und epistemologischen Fundierung eines pragmatischen Forschungsstils. 3rd ed. Wiesbaden, Germany: Springer. https://doi .org/10.1007/978-3-531-19897-2.

Tokar, B. (2015). 'Democracy, localism and the future of the climate movement'. World Futures 71 (3-4), pp. 65-75. https://doi.org/10.1080/02604027.2015.1092785.

Turner, S. (2007). 'Political epistemology, experts and the aggregation of knowledge'. Spontaneous Generations: A Journal for the History and Philosophy of Science 1 (1), pp. 36-47. https://doi.org/10.4245/sponge.v1i1.2970.

Weick, K. E. (2001). Making sense of the organization. Malden, MA, U.S.A.: Blackwell Publishing.

Wilson, K. M. (2000). 'Drought, debate and uncertainty: measuring reporters' knowledge and ignorance about climate change'. Public Understanding of Science 9 (1), pp. 1-13. https://doi.org/10.1088/0963-6625/9/1/301.

Yearley, S. (2014). 'Environmentalists as communicators of science: advocates and critics'. In: Routledge handbook of public communication of science and technology. Ed. by M. Bucchi and B. Trench. 2nd ed. London, U.K.: Routledge, pp. 113-124. https://doi.org/10.4324/9780203483794.ch9.

Yeo, S., Handlos, Z., Karambelas, A., Su, L. Y.-F., Rose, K., Brossard, D. and Griffin, K. (2017). 'The influence of temperature on \#ClimateChange and \#GlobalWarming discourses on Twitter'. JCOM 16 (5), A01.

Author

Birte Fähnrich, Dr., is senior researcher at the Center for Political Communication at Zeppelin University. She is the speaker of the Science Communication Division of the German Communication Association and a member of the Committee of the Network for the Public Communication of Science PCST.

E-mail: birte.faehnrich@zu.de.

\section{How to cite}

Fähnrich, B. (2018). 'Digging deeper? Muddling through? How environmental activists make sense and use of science - an exploratory study'. JCOM 17 (03), A08. https:/ / doi.org/10.22323/2.17030208. 